\title{
Penerapan Model Design Thinking pada Pengembangan Media Pembelajaran Berbasis Macro Media Flash
}

\author{
Muhamad Ali Kasri ${ }^{1}$, Yerlin Novan ${ }^{2}$, Indri Anugrah Ramadhani ${ }^{3}$ \\ Universitas Pendidikan Muhammadiyah Sorong ${ }^{1,3}$, Universitas Halu Uleo ${ }^{2}$ \\ muhamadalikasri@gmail.com ${ }^{1}$, nofanyerlin@gmail.com ${ }^{2}$, indianugrah18@gmail.com
}

\begin{abstract}
Abstrak: Pengembangan media pembelajaran IPA kelas VI SD Negeri 26 Malabutor Kota Sorong bertujuan memperbaharui pembelajaran konvseional dengan metode ceramah menjadi media pembelajaran berbasis teknologi. Jenis penelitian ini adalah research and development $(R \& D)$ dengan model design thinking yang terdiri dari tahap empathize, define, ideate, prototype, testing, dan implement. Teknik pengumpulan data melalui observasi, wawancara, dan studi pustaka. Prototype pengembangan media pembelajaran menggunakan metode Multimedia Development Life Cycle (MDLC) yang terdiri dari 6 tahap yaitu concept, design, material collecting, assembly, testing, dan distribution. Software yang digunakan dalam pengembangan media yaitu macromedia flash 8 , untuk desain menggunakan corel draw $x 7$ dan adobe photoshop cs3. Pengujian media menggunakan black box testing. Uji coba kelayakan media menggunakan skala likert dengan hasil uji coba perorangan persentase $82 \%$, uji coba kelompok kecil persentase $85 \%$, uji coba kelompok besar persentase $87 \%$. Skala Aiken $V$ untuk menentukan hasil validasi ahli materi dengan persentase 93\% dan validasi dari ahli media dengan persentase $85 \%$ sehingga termasuk dalam kategori sangat layak. Kata kunci : Media; Pembelajaran IPA; Design thinking; MDLC
\end{abstract}




\section{Pendahuluan}

Pengaruh dari perkembangan teknologi informasi sangat mendorong perubahan yang besar pada aspek pendidikan. Dalam ranah proses pembelajaran di sekolah teknologi informasi dapat mempercepat aliran ilmu pengetahuan yang mampu menembus batas-batas dimensi ruang, birokrasi, kemapanan dan waktu. Perkembangan ilmu pengetahuan dan teknologi semakin mendorong upayaupaya pembaharuan dalam pemanfaatan hasil teknologi dalam melaksanakan kegiatan proses belajar mengajar (Wibawanto, 2017). Pada era digital sekarang ini penggunaan teknologi sangat diperlukan dalam lembaga pendidikan, baik itu berhubungan dengan keperluan administrasi, pembuatan bahan ajar, bahkan dalam menyampaikan materi kepada peserta didik.

SD Negeri 26 Malabutor merupakan salah satu sekolah dasar yang berada di Kota Sorong Provinsi Papua Barat dengan Visi menjadikan sekolah terpecaya dimasyarakat dalam rangka mencerdaskan bangsa untuk mensukseskan wajib belajar. Salah satu misinya yaitu menyiapkan generasi unggul yang memiliki potensi optimal di bidang Iman dan Taqwa (IMTAQ) dan Ilmu Pengetahuan dan Teknologi (IPTEK) (Profil, 2018). Berdasarkan observasi dan hasil wawancara dengan salah satu guru kelas VI. Proses belajar mengajar yang dilakukan oleh guru masih bersifat konvensional seperti guru menyampaikan materi dengan metode ceramah, peserta didik hanya mendengarkan apa yang dijelaskan guru dan peserta didik hanya bisa menvisualkan dalam pikiran mereka. Sebagai yang dicontohkan pada mata pelajaran IPA Bab Ciri Khusus Makhluk Hidup dan Lingkungan Hidupnya. Peserta didik hanya bisa menghayal bagaimana bentuk nyata atau visual dari hewan $\mathrm{X}$, bagaimana bentuk dari tumbuhan $\mathrm{Y}$ dan lain sebagainya sehingga mengakibatkan kurangnya pemahaman peserta didik terhadap materi pelajaran yang disampaikan oleh guru. Selain itu para guru di SD Negeri 26 Malabutor Kota Sorong juga belum memanfaatkan media pembelajaranberbasis teknologi. Sementara sebagian guru memiliki personal komputer/laptop yang bisa digunakan untuk membuat media pembelajaran. Hal ini dikarenakan para guru kurang dilatih untuk mengoptimalkan multimedia dalam pembelajaran. Permasalahan iniperlu mendapat perhatian serius mengingat manfaatan media pembelajaran memiliki peranan yang sangat penting dalam pembelajaran sekolah dasar dimana optimalisasi multimedia mampu membuat pembelajaran lebih efektif (Lee 2006).

Dalam kaitannya dengan usaha untuk mencapai Misi SD Negeri 26 Malabutor Kota Sorong media pembelajaran menjadi salah satu peran yang sangat penting agar bisa unggul di bidang ilmu pengetahuan dan teknologi. Guru diharuskan mampu dalam menggunakan dan memanfaatkan teknologi, dalam hal ini menggunakan media pembelajaran berbasis teknologi. Media pembelajaran merupakan sarana yang dapat membantu proses pembelajaran karena berkaitan dengan indera pendengaran dan penglihatan. (Wibawanto, 2017). Media pembelajaran sangat membantu siswa yang sedang dalam memahami materi yang bersifat abstrak atau kurang mampu dijelaskan dengan bahasa verbal. Kerumitan bahan yang akan disampaikan juga dapat disederhanakan dengan bantuan media pembelajaran sehingga peserta didik dapat lebih cepat dalam memahami materi pelajaran (Batubara, 2015).Tiga alasan yang logis penggunaan multimedia dalam pembelajaran di kelas, yaitu menambah minat belajar peserta didik, meningkatkan pemahaman peserta didik, dan meningkatkan daya ingat peserta didik (Gilakjani, 2012).

Dalam penelitian sebelumnya yang dilakukan oleh Novitasari (2013) dengan judul Pengembangan Media Pembelajaran Berbasis TI Berbentuk Permainan Ular Tangga Materi Alat Optik Untuk Kelas VIII SMP. Metode penelitian yang digunakan adalah research and development $(r \& d)$ dengan tujuan untuk mengembangkan media pembelajaran berbasis IT berbentuk permainan ular tangga yang baik untuk materi fisika smp kelas VIII materi alat optik. Pengembangkan aplikasi media pembelajaran menggunakan macromedia flash professional 8. Penelitian ini juga menggunakan validasi ahli materi, validasi ahli media, dan uji coba siswa.

Penelitian sejenis juga pernah dilakukan oleh Satria (2015) dengan judul Perancangan Aplikasi Pembelajaran "Fruvenimal" Berbasis HTML5. Tujuan dari penelitian ini yaitu untuk mengembangkan sebuah aplikasi multimedia yang dapat menjadi media pengenalan fruvenimal. Metode pengembangan media pembelajaran yang digunakan yaitu Multimedia Development Life Cycle (MDLC). Pengujian produk menggunakan metode black box testing. 
Perumusan masalah yang dapat diambil dari latar belakang di atas yaitu pengembangan media pembelajaran untuk memudahkan metode pengajaran yang digunakan guru kepada peserta didik untuk lebih memahami materi dengan jelas dan nyata. Belum adanya visualisasi yang baik dan menarik dalam menjelaskan materi pelajaran IPA kepada peserta didik. Pembelajaran yang bersifat konvensional dengan metode ceramah hanya membatasi daya pikir peserta didik, akan lambat dalam memahami penjelasan materi dari guru. Batasan masalah pada penelitian ini yaitu pengembangan aplikasi media pembelajaran berbasis macromedia flash 8 . Media pembelajaran ini di khususkan pada kelas VI mata pelajaran IPA.

Tujuan dari penelitian ini agar proses pembelajaran IPA yang masih menggunakan metode ceramah bisa diganti dengan media pembelajaran interaktif dan mudah dimengerti oleh peserta didik dan membuat proses belajar lebih menarik. Dapat membantu guru dalam memberikan pelajaran IPA kepada peserta didik SD Negeri 26 Malabutor Kota Sorong dan membuat media pembelajaranberupa animasi, gambar, suara dan video. Manfaat yang diharapkan pada pengembangan media pembelajaran ini pelaksanaan pembelajaran dikelas akan lebih menarik dan akan terselanggara denga baik.

\section{Metode Penelitian}

Penelitian dan pengambangan atau sering disebut dengan Research and Development $(R \& D)$ merupakan metode penelitian yang digunakan untuk mengembangkan atau menguji efektivitas produk (Sugiono, 2013). Terdapat berbagai macam model pengembangan yang dapat digunakan pada kerangka Research and Development, salah satunya dengan menggunakan pendekatan design thinking yang termasuk pada ranah human-centered yang telah dipopulerkan oleh Kelley (IDEO, 2018). Design thinking didefinisikan sebagai proses pemikiran, kemampuan berpikir, inovasi atau proses pengembangan produk baru, alat pemecahan masalah, dan panduan langkah demi langkah untuk sebuah inovasi. Semua pengembangan ini tampaknya memiliki satu kesamaan, design thinking membantu dalam berurusan dengan inovasi (Carr, 2010). Yang istimewa dari design thinking adalah proses kerjanya dapat membantu mengekstrak, mengajar, belajar, dan menerapkan teknik yang berpusat pada manusia secara sistematis dalam menyelesaikan masalah dengan cara yang kreatif dan inovatifdalam lingkup bisnis,negara, sekolah, dan dalam kehidupan sehari-hari. Design thinking merupakan rangkaian proses yang dapat mencetuskan inovasi terbaru yang dapat digunakan pada research and development untuk mencari tahu masalah, membuat model terbaru hingga penyelesaian menggunakan protipe atau purwarupa. Kemampuan design thinking akan lebih mendasarkan pada pola-pola baru penciptaan karena dalam prosesnya lebih menitikberatkan kepada aktivitas persepsi, posibilitas, dan praktek. Proses design thinking yang digunakan untuk Research and Development telah bertransformasi menjadi 6 tahap yaitu Empathize, Define, Ideate, Prototype, Test, dan Implement (Gibson, 2016).

\section{Hasil dan Pembahasan}

Penelitian ini menerapkan metode design thinking sebagaimana seperti yang digunakan oleh Tim Brown dalam memecahkan masalah. Metode ini dinilai sangat efektif karena dapat menghasilkan solusi yang sesuai dengan kebutuhan pengguna. Berdasarkan tahap-tahap design thinking di atas maka penelitian yang akan dilakukan sesuai dengan tahap-tahap tersebut.

\section{Empathize}

Empathize merupakan tahap awal dari metode design thinking. Tahap ini bertujuan untuk menganalisi masalah dan kebutuhan dalam mengumpulkan informasi seperti melakukan pengamatan terhadap media yang digunakan, menganalisis kompetensi inti dan kompetensi dasar. Informasi dikumpulkan melalui wawancara kepada guru kelas VI dan observasi langsung kepada peserta didik. Sementara obeservasi yang dilakukan kepada peserta didik yaitu langsung berinteraksi dengan 46 peserta didik kelas VI yang terbagi dua kelas pada saat proses pembelajaran IPA sedang berlangsung. Kelas VI A terdiri dari 22 peserta didik dan kelas VI B terdiri dari 24 peserta didik. Pada tahap ini peneliti menanyakan beberapa pertanyaan kepada peserta didik terkait mata pelajaran IPA pada Bab Ciri Khusus Makhluk Hidup dan Lingkungan Hidupnya. Berdasarkan hasil wawancara dan observasi menunjukan bahwa di era teknologi yang berkembang pesat sekarang ini proses pembelajaran yang hanya menggunakan metode 
konvesional menjadi kurang efektif untuk diterapkan, sehingga diperlukan perubahan metode pembelajaran yang lebih efektif untuk menghasilkan prestasi yang baik kepada peserta didik.

\section{Define}

Pada tahap define ini data dan informasi yang dikumpulkan akan digunakan untuk memahami permasalahan yang ada dan kemudian dikerucutkan kedalam kesimpulan permasalahan yang paling urgent. Adapun masalah yang sudah dipilah berdasarkan hasil wawancara dan observasi dicantumkan dalam tabel 1.

Tabel 1. Permasalahan yang paling urgent

\begin{tabular}{clc}
\hline Kode & \multicolumn{1}{c}{ Permasalahan } & Persentase \\
\hline D1 & Pembelajaran pada umumnya masih bersifat konvensional. & $86 \%$ \\
\hline D2 & $\begin{array}{l}\text { Kurangnya inovasi guru dalam mengajar agar peserta didik tidak } \\
\text { merasa bosan dalam proses belajar }\end{array}$ & $79 \%$ \\
\hline D3 & $\begin{array}{l}\text { Peserta didik hanya menerima materi, menulis, dan mengikuti } \\
\text { semua yang diintruksikan guru }\end{array}$ & $79 \%$ \\
\hline D4 & Gaya belajar yang monoton dari awal sampai akhir pembelajaran & $71 \%$ \\
\hline D5 & Metode pembelajaran ceramah yang membosankan & $71 \%$ \\
\hline D6 & Materi yang kurang menarik & $71 \%$ \\
\hline D7 & Guru tidak menggunakan teknologi dalam proses belajar mengajar & $64 \%$ \\
\hline D8 & Tidak ada pelatihan pembuatan media pembelajaran & $57 \%$ \\
\hline D9 & $\begin{array}{l}\text { Peserta didik kesulitasn dalam memahami isi, contoh-contoh dan } \\
\text { bahasa dalam buku teks }\end{array}$ & $43 \%$ \\
\hline D10 & $\begin{array}{l}\text { Peserta didik lebih tertarik berbicara dengan teman sejawatnya } \\
\text { daripada memperhatikan guru yang sedang menjelaskan materi di } \\
\text { depan kelas. }\end{array}$ & $43 \%$ \\
\hline D11 & Suasana peserta didik yang ribut di kelas & $36 \%$ \\
\hline
\end{tabular}

Dari persentase jawaban guru SD Negeri 26 Malabutor Kota Sorong peneliti akan mencari informasi yang dapat dimasukkan kedalam proses kreatif pada tahap berikutnya.

\section{Ideate}

Ideate adalah mode dari proses desain dimana lebih terfokus pada pembuatan ide. Secara mental merupakan proses melebar dalam hal konsep dan hasil. Ideate menyediakan pola untuk membuat prototype dan mendapatkan solusi inovatif untuk menyelesaikan masalah guru dan peserta didik (d.school, 2019). Ideate merupakan proses yang sangat menarik karena akan menghasilkan sejumlah ide yang banyak dan berpotensi yang kemudian dapat dipilih menjadi ide yang terbaik. Pada tahap ideate ini brainstorm akan digunakan untuk memperoleh ide sebagai solusi dari masalah yang ada. Brainstorming adalah cara yang bagus untuk menghasilkan banyak ide dengan memanfaatkan pemikiran guru, peserta didik dan peneliti dengan terlibat satu sama lain, mendengarkan, dan membangun ide-ide lain. Kemudian membangun tanggapan dan ide dengan tujuan menghasilkan solusi. Adapun solusi yang didapat dari hasil brainstorming di uraikan pada Tabel 2.

Tabel 2. Solusi Permasalahan

\begin{tabular}{|c|c|c|}
\hline Kode & Permasalahan & Solusi \\
\hline D1 & $\begin{array}{lllll}\begin{array}{l}\text { Pembelajaran pada umumnya masih } \\
\text { konvensional. }\end{array} & \text { bersifat } \\
\end{array}$ & \multirow{6}{*}{$\begin{array}{l}\text { Membuat media } \\
\text { pembelajaran interaktif } \\
\text { untuk menarik } \\
\text { perhatian peserta didik }\end{array}$} \\
\hline D3 & $\begin{array}{l}\text { Peserta didik hanya menerima materi, menulis, dan } \\
\text { mengikuti semua yang diintruksi guru }\end{array}$ & \\
\hline D4 & $\begin{array}{l}\text { Gaya belajar yang monoton dari awal sampai akhir } \\
\text { pembelajaran }\end{array}$ & \\
\hline D5 & $\begin{array}{l}\text { Metode pembelajaran ceramah hanya membuat peserta } \\
\text { didik merasa bosan dalam proses belajar }\end{array}$ & \\
\hline D6 & Materi yang kurang menarik & \\
\hline D2 & Kurangnya inovasi guru dalam mengajar agar peserta & \\
\hline
\end{tabular}




\begin{tabular}{|c|c|c|}
\hline & didik tidak merasa bosan dalam proses belajar & \\
\hline D7 & $\begin{array}{l}\text { Guru tidak menggunakan teknologi dalam proses } \\
\text { belajar mengajar }\end{array}$ & \\
\hline D9 & $\begin{array}{l}\text { Peserta didik kesulitasn dalam memahami isi, contoh- } \\
\text { contoh dan bahasa dalam buku teks }\end{array}$ & \\
\hline D10 & $\begin{array}{l}\text { Peserta didik lebih tertarik berbicara dengan teman } \\
\text { sejawatnya daripada memperhatikan guru yang sedang } \\
\text { menjelaskan materi di depan kelas. }\end{array}$ & \multirow{2}{*}{$\begin{array}{lr}\text { Gunakan } & \text { metode } \\
\text { mengajar } & \text { yang } \\
\text { membuat } & \text { siswa lebih } \\
\text { fokus pada pelajaran }\end{array}$} \\
\hline D11 & Suasana peserta didik yang ribut di kelas & \\
\hline D8 & Tidak ada pelatihan pembuatan media pembelajaran & $\begin{array}{l}\text { Workshop pembuatan } \\
\text { media pembelajaran. }\end{array}$ \\
\hline
\end{tabular}

Tabel di atas merupakan ide dari guru dan peserta didik sebagai solusi yang dialami pada proses pembelajaran. Peneliti telah menampung dan memilah solusi mana yang lebih layak untuk diterapkan sebagaimana solusi yang tertera pada tabel di atas.

\section{Prototype}

Dalam design thinking tidak cukup hanya memikirkan, mendiskusikan dan menentukan ide. Perlu adanya langkah konkrit untuk membuatnya menjadi nyata. Salah satu cara terbaik untuk mendapatkan wawasan dalam proses design thinking adalah dengan melakukan beberapa bentuk prototype. Pada tahap prototype ini melibatkan pembuatan mockup yang menyampaikan esensi ide atau solusi yang sudah disepakati pada tahap ideate. Tujuan penting dari tahap prototype ini adalah memusatkan perhatian pada ide atau solusi yang akan diimplementasikan dalam sebuah aplikasi atau produk uji coba berupa media pembelajaran. Tahap prototype ini akan menggunakan metode Multimedia Development Life Cycle(MDLC), model pengembangan versi Luther ini terdiri dari 6 tahap, yaitu concept, design, material collecting, assembly, testing, dan distribution (Luther dalam Sutopo, $2012: 128$ ).

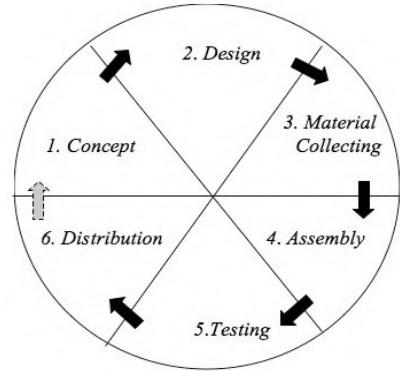

1. concept

Gambar 1. Multimedia Development Life Cycle

Pada tahap concept ini menentukan dan merancang jenis aplikasi multimedia yang akan dibuat. Dalam penentuan dan perancangan media pembelajaran ini akan mengacu pada keperluan guru dan peserta didik. Tujuan dari konsep media pembelajaran ini yaitu untuk merancang dan mengimplementasikan media pembelajaran berbasis flash pada kelas VI SD Negeri 26 Malabutor Kota Sorong. Media pembelajaran ini diharapkan dapat meningkatkan motivasi belajar peserta didik. Sasaran utama media pembelajaran ini adalah peserta didik kelas VI mata pelajaran IPA sehingga akan dibuat semenarik mungkin dengan gabungan antara teks, audio, video, gambar dan animasi.

2. design

Tahap ini akan membuat rancangan terhadap media pembelajaran, menggambarkan secara detail bagian-bagian dari media pembelajaran. Tahap ini meliput pembuatan flowchart dan storyboard.

a. Flowchart

Pada tahap ini flowchart berfungsi sebagai penggambaran secara menyeluruh tentang alur program yang dibuat dengan simbol-simbol tertentu. Hal ini sangat penting bagi pengembang guna memudahkan dalam perancangan media pembelajaran dari awal sampai akhir agar media pembelajaran tergambar secara utuh. Gambaran rancangan media pembelajaran dapat dilihat pada gambar 2 . 


\section{b. Storyboard}

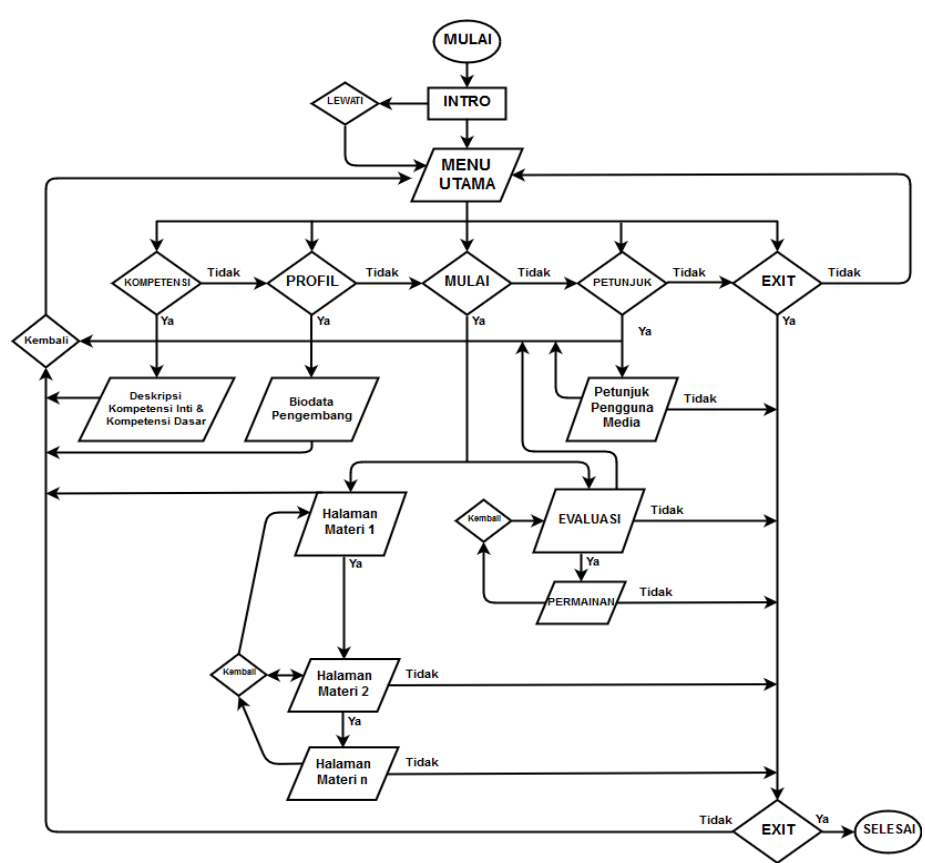

Gambar 2. Flowchart Rancangan Media Pembelajaran

Storyboard digunakan untuk membuat outline media pembelajaran. Bagi pengembang mulimedia, storyboard merupakah pedoman dari aliran pekerjaan yang harus dilakukan (Septiana, 2012). Pada alur diagram rancangan media pembelajaran dari tahap awal sampai akhir hanya berisi garis besar. Maka penjelasan lebih lengkap pada alur diagram akan dijelaskan pada tahap storyboard. Adapun storyboard media pembelajaran IPA SD Negeri 26 Malabutor Kota Sorong adalah sebagai berikut.

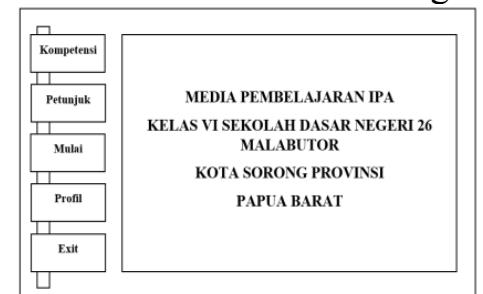

Gambar 3. Storyboard Halaman Menu Utama

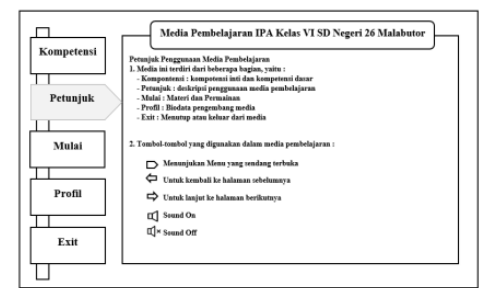

Gambar 5. Storyboard Halaman Petunjuk

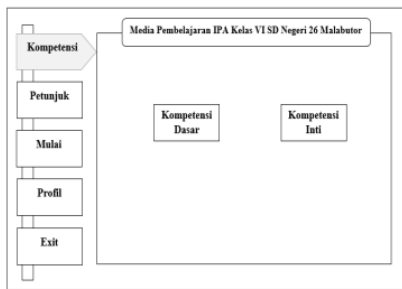

Gambar 4. Storyboard Halaman Kompetensi

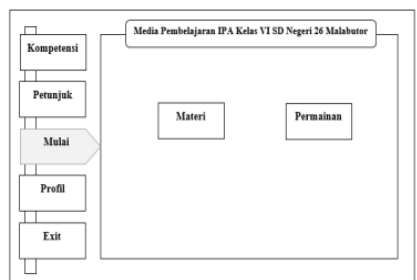

Gambar 6. Storyboard Halaman Mulai 


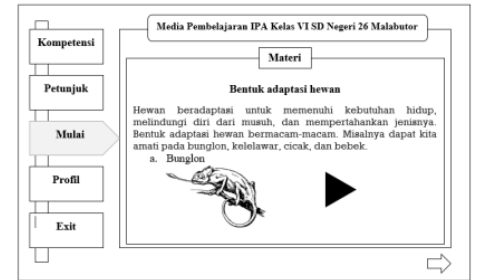

Gambar 7. Stroyboard Halaman Materi

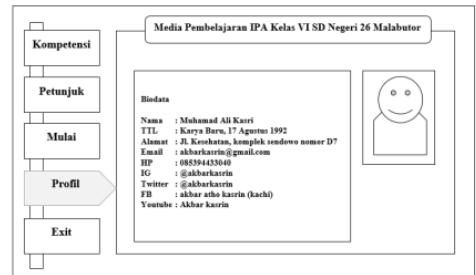

Gambar 8. Stroyboard

Halaman Profil

Penjelasan storyboard tertera pada tabel 3 :

Tabel 3. Deskripsi Storyboard Media Pembelajaran

\begin{tabular}{lll}
\hline Nama Scene & Deskripsi & Action \\
\hline $\begin{array}{l}\text { Scene Menu } \\
\text { Utama }\end{array}$ & $\begin{array}{l}\text { Halaman ini akan } \\
\text { menampilkan menu } \\
\text { utama dari media } \\
\text { pembelajaran }\end{array}$ & $\begin{array}{l}\text { Halaman menu utama ini terdiri dari } \\
\text { menu utama yaitu menu kompetensi, } \\
\text { menu petunjuk, menu mulai, menu } \\
\text { profil, dan exit }\end{array}$ \\
\hline $\begin{array}{l}\text { Scene } \\
\text { halaman } \\
\text { kompetensi }\end{array}$ & $\begin{array}{l}\text { Halaman ini } \\
\text { menampilkan isi menu } \\
\text { kompetensi }\end{array}$ & $\begin{array}{l}\text { Menu kompetensi terdiri dari dua sub } \\
\text { menu yaitu Kompetensi Dasar dan } \\
\text { Kompetensi Inti. }\end{array}$ \\
\hline $\begin{array}{l}\text { Scene } \\
\text { halaman } \\
\text { petunjuk }\end{array}$ & $\begin{array}{l}\text { Halaman ini } \\
\text { menampilkan petunjuk }\end{array}$ & $\begin{array}{l}\text { Menu petunjuk berisi panduan } \\
\text { penggunaan mendia pembelajaran. }\end{array}$ \\
\hline $\begin{array}{l}\text { Scene } \\
\text { halaman } \\
\text { mulai }\end{array}$ & $\begin{array}{l}\text { Halaman ini } \\
\text { menampilkan dua sub } \\
\text { menu }\end{array}$ & $\begin{array}{l}\text { Halaman menu mulai berisi dua sub } \\
\text { menu yaitu materi yang berisi materi }\end{array}$ \\
& & $\begin{array}{l}\text { IPA kelas VI SD Negeri 26 Malabutor } \\
\text { Kota Sorong dan permainan berisi } \\
\text { evaluasi berupa soal latihan tebak } \\
\text { gambar. }\end{array}$ \\
\hline $\begin{array}{l}\text { scene halaman } \\
\text { materi }\end{array}$ & $\begin{array}{l}\text { Halaman ini berisi } \\
\text { materi }\end{array}$ & $\begin{array}{l}\text { Halaman materi berisi tentang materi } \\
\text { pembelajaran IPA Kelas VI SD } \\
\text { Negeri 26 Malabutor Kota Sorong. }\end{array}$ \\
\hline $\begin{array}{l}\text { Scene } \\
\text { halaman } \\
\text { profil }\end{array}$ & $\begin{array}{l}\text { Halaman ini berisi } \\
\text { biodata pengembang } \\
\text { media }\end{array}$ & $\begin{array}{l}\text { Halaman ini berisi biodata } \\
\text { pengembang media pembelajaran }\end{array}$ \\
\hline
\end{tabular}

3. Material collecting

Pada tahap ini dilakukan pengumpulan bahan-bahan materi yang sesuai dengan kebutuhan media pembelajaran berupa materi, data, audio, video, dan gambar. Dalam pengembangan multimedia pembelajaran, materi diperoleh pada tahap wawancara kepada guru mata pelajaran, membaca buku dan mencari sumber lain yang sesuai dengan pembelajaran IPA kelas VI di SD Negeri 26 Malabutor Kota Sorong. Perangkat keras yang digunakan pada pembuatan media pembelajaran ini adalah PC/ Laptop dengan spesifikasi : procesor Intel core i5, memory 4 GB dan monitor 14.0. Perangkat lunak yang digunakan dalam pembuatan media pembelajaran yaitu sistem operasi windows 10 pro, untuk membuat aplikasinya menggunakan software macromedia flash 8.

4. Assembly

Pada dasarnya tahap ini merupakan tahap utama dalam membuat media pembelajaran. Assembly adalah tahap menggabungkan berbagai teks, gambar, animasi, video, grafik yang disusun berdasarkan storyboard. Pembuatan media pembelajaran ini menggunakan software macromedia flash 8 , sedangkan untuk desain menggunakan software corel draw $x 7$ dan adobe photoshop cs3. Proses pembuatan media pembelajaran berdasarkan proses desain sebagai berikut : 


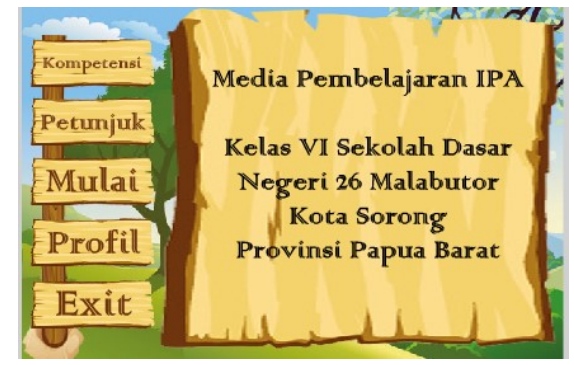

Gambar 9. Halaman Menu Utama

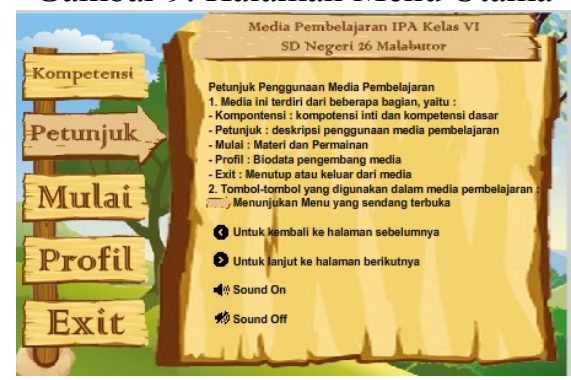

Gambar 11. Halaman Petunjuk

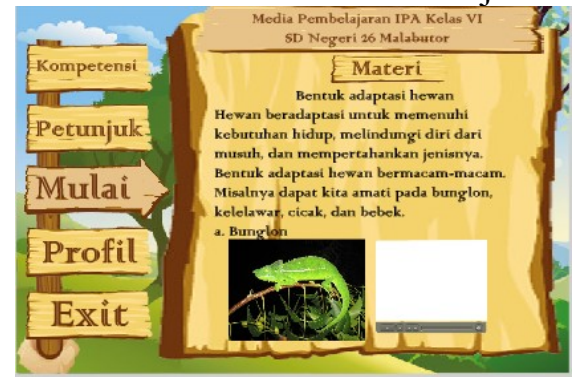

Gambar 13. Halaman Materi

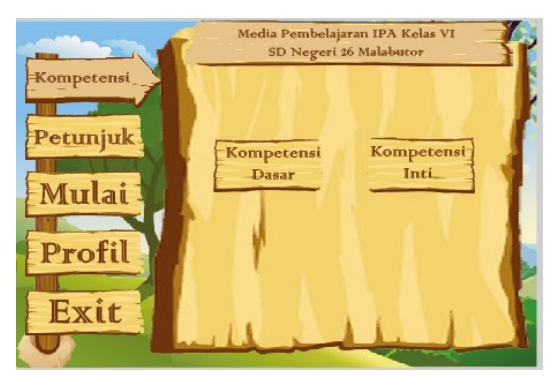

Gambar 10. Halaman Kompetensi

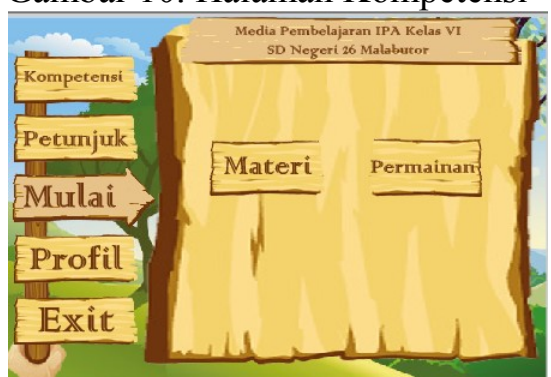

Gambar 12. Halaman Mulai

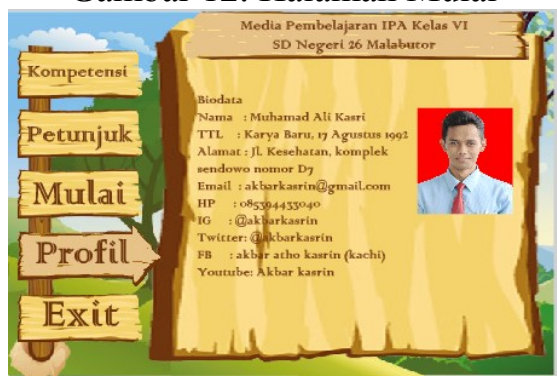

Gambar 14. Halaman Profil

\section{Testing}

Tahap testing dilakukan setelah tahap assembly selesai yaitu dengan menjalankan media pembelajaran untuk ditinjau guna mengetahui ada atau tidak adanya kesalahan pada media. Media dijalankan dan diperiksa untuk memastikan bahwa pengembangan multimedia yang dilakukan sesuai dengan apa yang telah direncanakan. Pengujian yang dilakukan terhadap media pembelajaran ini menggunakan metode black box testing. Metode black box testing merupakan pendekatan pengujian untuk mengetahui apakah semua fungsi media pembelajaran telah berjalan semestinya sesuai dengan kebutuhan fungsional yang telah didefinsikan (Pressman, 2010). Tujuan dari metode black box testing adalah untuk menemukan kesalahan pada fungsi aplikasi. Pengujian aplikasi ini berfokus pada persyaratan fungsional media pembelajaran. Dari hasil pengujian yang dilakukan dapat dilihat pada tabel 4.

Tabel 4. Hasil Pengujian Media Pembelajaran

\begin{tabular}{lllc}
\hline Nama Pengujian & Bentuk Pengujian & Hasil Yang Diharapkan & Hasil Pengujian \\
\hline Memuat halaman & Membuka aplikasi & Tampilan Intro & Berhasil \\
\hline Loading (memuat data) & Membuka aplikasi & Tampilan halaman menu utama & Berhasil \\
\hline $\begin{array}{l}\text { Pengujian menu } \\
\text { kompetensi }\end{array}$ & $\begin{array}{l}\text { Klik tombol } \\
\text { kompetensi }\end{array}$ & $\begin{array}{l}\text { Tampilan halaman sub menu } \\
\text { kompetensi dasar dan kompetensi } \\
\text { inti }\end{array}$ & Berhasil \\
\hline $\begin{array}{l}\text { Pengujian menu } \\
\text { kompetensi dasar }\end{array}$ & $\begin{array}{l}\text { Klik tombol } \\
\text { kompetensi dasar }\end{array}$ & $\begin{array}{l}\text { Tampilan halaman deskripsi } \\
\text { kompetensi dasar }\end{array}$ & Berhasil \\
\hline $\begin{array}{l}\text { Pengujian menu } \\
\text { kompetensi inti }\end{array}$ & $\begin{array}{l}\text { Klik tombol } \\
\text { kompetensi inti }\end{array}$ & $\begin{array}{l}\text { Tampilan halaman deskripsi } \\
\text { kompetensi inti }\end{array}$ & Berhasil \\
\hline $\begin{array}{l}\text { Pengujian menu } \\
\text { petunjuk }\end{array}$ & $\begin{array}{l}\text { Klik tombol } \\
\text { petunjuk }\end{array}$ & Tampilan halaman petunjuk & Berhasil \\
\hline Pengujian menu mulai & Klik tombol mulai & $\begin{array}{l}\text { Tampilan halaman sub menu } \\
\text { materi dan sub menu permainan }\end{array}$ & Berhasil \\
\hline
\end{tabular}




\begin{tabular}{|c|c|c|c|}
\hline Pengujian menu materi & Klik tombol materi & Tampilan halaman materi & Berhasil \\
\hline $\begin{array}{l}\text { Pengujian menu } \\
\text { permainan }\end{array}$ & $\begin{array}{l}\text { Klik tombol } \\
\text { permainan }\end{array}$ & Tampilan halaman permainan & Berhasil \\
\hline $\begin{array}{l}\text { Pengujian halaman } \\
\text { profil }\end{array}$ & Klik tombol profil & $\begin{array}{l}\text { Tampilan halaman biodata } \\
\text { pengembang }\end{array}$ & Berhasil \\
\hline $\begin{array}{l}\text { Pengujian tombol } \\
\text { kembali }\end{array}$ & Klik tombol back & Kembali ke halaman sebelumnya & Berhasil \\
\hline $\begin{array}{l}\text { Pengujian tombol } \\
\text { selanjutnya }\end{array}$ & Klik tombol next & Lanjut kehalaman berikut & Berhasil \\
\hline $\begin{array}{l}\text { Pengujian tombol sound } \\
\text { off }\end{array}$ & Klik tombol sound & Suara media akan diam & Berhasil \\
\hline Pengujian tombol on & Klik tombol sound & Akan terdengar suara & Berhasil \\
\hline Pengujian tombol play & $\begin{array}{l}\text { Klik tombol play } \\
\text { pada video }\end{array}$ & Tampilan video pembelajaran & Berhasil \\
\hline Pengujian halaman exit & Klik tombol exit & $\begin{array}{l}\text { Muncul pertanyaan konfirmasi } \\
\text { keluar tombol ya dan tombol } \\
\text { tidak }\end{array}$ & Berhasil \\
\hline
\end{tabular}

\section{Distribution}

Tahap ini media pembelajaran telah digandakan dan siap didistribusikan untuk uji coba kelayakan. Uji coba kelayakan media pembelajaran ini akan di distribusikan kepada ahli materi dan ahli media. Kemudian didistribusikan kepada peserta didik kedalam tiga kelompok yaitu uji coba perorangan, uji coba kelompok kecil, dan uji coba kelompok besar.

Untuk menentukan tingkat kelayakan media pembelajaran yang telah didistribusikan ini menggunakan angket penilian. Jenis angket yang digunakan mengacu pada penilaian Skala Likert. Skala Likert digunakan untuk mengukur sikap, pendapat, dan persepsi seseorang atau sekelompok orang (Sugiono, 2013 :136-137). Uji coba media pembelajaran ini melibatkan 3 ahli materi untuk menguji kelayakan materi, 2 ahli media untuk menguji kelayakan media, 5 peserta didik untuk uji perorangan, 15 peserta didik untuk uji coba kelompok kecil, dan 46 peserta didik untuk uji coba kelompok besar.

Dalam uji coba media pemebelajaran ini kriteria jawaban item instrumen penilaian mengacu pada tabel 7 dan kriteria persentase indikator media mengacu pada tabel 8 berikut ini.

Tabel 5. Kriteria Jawaban

Instrumen Penilian

\begin{tabular}{clc}
\hline No & Kriteria Jawaban & Skor \\
\hline $\mathbf{1}$ & Sangat Setuju & 4 \\
\hline $\mathbf{2}$ & Setuju & 3 \\
\hline $\mathbf{3}$ & Kurang Setuju & 2 \\
\hline $\mathbf{4}$ & Sangat Tidak Setuju & 1 \\
\hline
\end{tabular}

Tabel 6. Kriteria Persentase Indikator Media

\begin{tabular}{cl}
\hline Interval Persentase & Kriteria \\
\hline $\mathbf{8 0 \%}-\mathbf{1 0 0 \%}$ & Sangat Baik \\
\hline $\mathbf{6 0 \%}-\mathbf{8 0 \%}$ & Baik \\
\hline $\mathbf{4 0 \%}-\mathbf{6 0 \%}$ & Sedang \\
\hline $\mathbf{2 0 \%}-\mathbf{4 0 \%}$ & Kurang Baik \\
\hline $\mathbf{0 \%}-\mathbf{2 0 \%}$ & Sangat Kurang Baik \\
\hline
\end{tabular}

(Sugiono, $2012:$ 137).

Kemudian dianalis menggunakan statistik deskriptif yaitu skor rata-rata dan persentase. Persentase skor ini dihitung menggunakan rumus perhitungan berikut ini. Persentase Skor $=\frac{\text { Jumlah Skor per Kategori }}{\text { Jumlah total } \text { kategori }} \times 100 \%$

Penilaian kelayakan media pembelajaran ini dikategorikan ke dalam empat bagian seperti yang tertera pada tabel berikut.

Tabel 7. Skala Pesentase Kelayakan Media Pebelajaran

\begin{tabular}{cc}
\hline Skor dalam persen & Interprestasi \\
\hline $\mathbf{8 0 - 1 0 0 \%}$ & Sangat Layak \\
\hline $\mathbf{6 0 - 8 0} \%$ & Layak \\
\hline $\mathbf{4 0 - 6 0 \%}$ & Cukup Layak \\
\hline $\mathbf{2 0 - 4 0 \%}$ & Kurang Layak \\
\hline$<\mathbf{2 0} \%$ & Sangat tidak layak \\
\hline
\end{tabular}


(Riduan, 2010).

Sementara untuk mengetahui kelayakan media pembelajaran yaitu melalui validasi ahli materi dan ahli media dengan menggunakan skala Aiken $V$ dengan rumus sebagai berikut (Heri Retnawati, 2016: 18):

Keterangan : $\quad V=\sum \mathrm{s} /[\mathrm{n}(\mathrm{c}-1)]$

$$
V=\frac{\sum s}{n(C-1)}
$$

$\mathrm{S}=\mathrm{r}-1 \mathrm{o}$

Lo $=$ angka penilaian validitas yang terendah (misalnya 1$)$

$\mathrm{C}=$ angka penilaian validitas tertinggi (misalnya 4$)$

$\mathrm{R}=$ angka yang diberikan penilai

Adapun kriteria penilaian validasi dapat dilihat pada tabel berikut :

Tabel 8. Validasi Berdasarkan Skala Aiken V

\begin{tabular}{clc}
\hline No. & Skala Aiken V & Validasi \\
\hline 1. & $V \leq 0,4$ & Kurang Valid \\
\hline 2. & $0,4<V \leq 0,8$ & Valid \\
\hline 3. & $0,8<V$ & Sangat Valid \\
\hline
\end{tabular}

5. Test

Pada tahap test metode design thinking ini yaitu uji coba kelayakan media pembelajaran. Pengujian materi pada media pembelajaran ini diserahkan kepada ahli materi pembelajaran yaitu guru mata pelajaran IPA dan dosen IPA untuk memberi penilaian. Berikut ini merupakan hasil uji validasi dari ahli materi dan ahli media.

Tabel 9. Uji Validasi Ahli Materi

\begin{tabular}{|c|c|c|c|}
\hline Komponen Yang Dinilai & $\begin{array}{c}\text { Nilai } \\
\text { Kolerasi }\end{array}$ & $\begin{array}{l}\text { Nilai } \\
\text { R }\end{array}$ & Kesimpulaı \\
\hline Kejelasan penguraian materi & 0,89 & 0,88 & Sangat Vali \\
\hline Konsep materi terhadap tujuan pembelajaran & 0,89 & 0,88 & Sangat Vali \\
\hline Kesesuaian materi dengan daya tangkap peserta didik & 0,78 & 0,88 & Valid \\
\hline Tingkat ketertarikan materi yang disampaikan oleh guru & 0,89 & 0,88 & Sangat Val \\
\hline Kemudahan dalam memahami materi yang disampaikan & 1,00 & 0,88 & Sangat Val \\
\hline Kelengkapan materi & 0,89 & 0,88 & Sangat Val \\
\hline Kesesuaian materi dengan silabus & 0,89 & 0,88 & Sangat Val \\
\hline Ketepatan penjelasan video dengan materi & 1,00 & 0,88 & Sangat Val \\
\hline Ketepatan gambar, animasi audio untuk mendukung materi & 1,00 & 0,88 & Sangat Val \\
\hline Kesesuaian soal dalam permainan dengan materi & 0,89 & 0,88 & Sangat Valic \\
\hline \multicolumn{4}{|c|}{$\begin{array}{l}\text { Berdasarkan uji validasi ahli materi diatas menunjukkan nilai rata-rata kolerasi } 0 \\
\text { dengan dengan persentase 93\%. Validasi ahli materi ini menunjukkan bahwa me } \\
\text { pembelajaran IPA kelas VI SD Negeri } 26 \text { Malabutor Kota Sorong termasuk kategori "san } \\
\text { layak" }\end{array}$} \\
\hline \multicolumn{4}{|c|}{ Tabel 10. Validasi Ahli Media } \\
\hline Komponen Yang Dinilai & $\begin{array}{l}\text { Nilai } \\
\text { Kolerasi }\end{array}$ & $\begin{array}{l}\text { Nilai } \\
\mathbf{R}\end{array}$ & Kesimpulan \\
\hline Tampilan menu pada media mudah digunakan & 0,89 & 0,88 & Sangat Valid \\
\hline Petunjuk penggunaan media pembelajaran & 0,78 & 0,88 & Valid \\
\hline Kemudahan dalam mengoperasikan media & 0,67 & 0,88 & Valid \\
\hline Interaksi pengguna denga media pembelajaran & 0,78 & 0,88 & Valid \\
\hline Konsistensi penempatan item pada media & 0,89 & 0,88 & Sangat Valid \\
\hline Kemudahan menggunakan navigasi & 0,78 & 0,88 & Valid \\
\hline Navigasi media jelas & 0,78 & 0,88 & Valid \\
\hline $\begin{array}{l}\text { Kejelasan teks, gambar, audio, animasi dan video } \\
\text { pada media }\end{array}$ & 0,78 & 0,88 & Valid \\
\hline Pemilihan warna pada media sangat menarik & 0,67 & 0,88 & Valid \\
\hline
\end{tabular}




\begin{tabular}{llll}
\hline Tampilan permainan sangat menarik & 1,00 & 0,88 & Sangat Valid
\end{tabular}

Berdasarkan uji validasi ahli media diatas menunjukkan nilai rata-rata kolerasi 0,80 dengan dengan persentase $85 \%$. Validasi ahli materi ini menunjukkan bahwa media pembelajaran IPA kelas VI SD Negeri 26 Malabutor Kota Sorong termasuk kategori "sangat layak"

Setelah mengetahui hasil validasi dari ahli materi dan ahli media, selanjutnya media ini akan uji coba kepada peserta didik yang dibagi atas tiga kelompok seperti yang tertera pada tabel berikut ini.

Tabel 11. Komponen-komponen yang dinilai pada Uji Coba Perorangan (U1), Uji Coba Kelompok Kecil (U2), dan Uji Coba Kelompok Besar (U3).

\begin{tabular}{|c|c|c|c|c|c|c|c|c|c|c|}
\hline \multirow[t]{2}{*}{ No } & \multirow[t]{2}{*}{ Komponen yang dinilai } & \multicolumn{3}{|c|}{ Jumlah $\left(\sum\right)$ skor } & \multicolumn{3}{|c|}{$\begin{array}{c}\text { Rata-rata Skor } \\
\left(\sum \text { skor/respond }\right. \\
\text { en })\end{array}$} & \multicolumn{3}{|c|}{ Persentase (\%) } \\
\hline & & U1 & U2 & U3 & U1 & U2 & U3 & U1 & U2 & U3 \\
\hline 1 & $\begin{array}{l}\text { Tampilan media } \\
\text { pembelajaran menarik }\end{array}$ & 19 & 51 & 154 & 3,8 & 3,4 & 3,3 & $95 \%$ & $85 \%$ & $84 \%$ \\
\hline 2 & $\begin{array}{l}\text { Tampilan menu pada } \\
\text { media }\end{array}$ & 15 & 48 & 135 & 3 & 3,2 & 2,9 & $75 \%$ & $80 \%$ & $73 \%$ \\
\hline 3 & $\begin{array}{l}\text { Kepahaman terhadap } \\
\text { materi }\end{array}$ & 17 & 52 & 164 & 3,4 & 3,5 & 3,6 & $85 \%$ & $87 \%$ & $89 \%$ \\
\hline 4 & Penyajian audio & 18 & 51 & 140 & 3,6 & 3,4 & 3,0 & $90 \%$ & $85 \%$ & $76 \%$ \\
\hline 5 & $\begin{array}{l}\text { Tampilan gambar ilustrasi } \\
\text { media }\end{array}$ & 16 & 52 & 154 & 3,2 & 3,5 & 3,3 & $80 \%$ & $87 \%$ & $84 \%$ \\
\hline 6 & $\begin{array}{l}\text { Penjelasan materi dalam } \\
\text { bentuk video }\end{array}$ & 18 & 53 & 158 & 3,6 & 3,5 & 3,4 & $90 \%$ & $88 \%$ & $86 \%$ \\
\hline 7 & $\begin{array}{l}\text { Kejelasan jenis dan } \\
\text { ukuran teks }\end{array}$ & 13 & 47 & 118 & 2,6 & 3,1 & 2,6 & $65 \%$ & $78 \%$ & $64 \%$ \\
\hline 8 & Tampilan animasi & 15 & 52 & 134 & 3 & 3,5 & 2,9 & $75 \%$ & $87 \%$ & $73 \%$ \\
\hline 9 & $\begin{array}{l}\text { Ketertarikan terhadap soal } \\
\text { latihan }\end{array}$ & 15 & 55 & 116 & 3 & 3,7 & 2,5 & $75 \%$ & $92 \%$ & $63 \%$ \\
\hline 10 & $\begin{array}{l}\text { Ketertarikan terhadap } \\
\text { permainan }\end{array}$ & 18 & 48 & 156 & 3,6 & 3,2 & 3,4 & $90 \%$ & $80 \%$ & $85 \%$ \\
\hline
\end{tabular}

Dari hasil uji coba pada tabel di atas dapat disimpulkan bahwa hasil uji coba perorangan menunjukkan hasil yang sangat baik dengan nilai rata-rata 3,3 dengan persentase $82 \%$. Uji kelompok kecil menunjukkan hasil sangat baik dengan nilai rata-rata 3,4 dengan persentase $85 \%$, dan uji coba skala besar menunjukkan hasil baik dengan nilai rata-rata 3,1 dengan persentase $78 \%$.

Setelah melalui tahap validasi dari para ahli, dilanjutkan tahap uji coba perorangan, uji coba kelompok kecil, dan uji coba kelompok besar menunjukan bahwa media pembelajaran IPA Kelas VI SD Negeri 26 Malabutor Kota Sorong dinyatakan sangat baik dengan kategori sangat layak dan tidak perlu direvisi.

6. Implement

Setelah dilakukan beberapa pengujian pada tahap sebelumnya dan mendapatkan hasil yang sangat baik maka tahap implement ini akan merepresentasikan media pembelajaran dengan memberikan hasil pembuatan media pembelajaran kepada guru dalam bentuk file yang sudah tersimpan dalam CD-ROM atau hardisk dengan format *exe dan siap untuk digunakan sebagai media untuk pembelajaran kepada peserta didik kelas VI SD Negeri 26 Malabutor Kota Sorong.

\section{Kesimpulan}

Berdasarkan perumusan masalah, tujuan penelitian, metode penelitian, hasil dan pembahasan media pembelajaran IPA Kelas VI SD Negeri 26 Malabutor Kota Sorong dapat disimpulkan dalam beberapa point antara lain hasil dari validasi ahli materi dan ahli media menunjukkan bahwa materi pembelajaran, kualitas media pembelajaran yang digunakan dinilai sangat baik dan layak untuk diterapkan. Kualitas materi media pembelajaran dari validasi ahli materi termasuk kriteria "Sangat Baik" sehingga layak digunakan dalam proses pembelajaran dengan persentase 93\%. Kualitas desain 
media termasuk kriteria "Sangat Baik" dengan persentase $85 \%$ dari validasi ahli media. Dari hasil validasi kedua ahli menunjukkan bahwa media pembelajaran IPA Kelas VI SD Negeri 26 Malabutor Kota Sorong termasuk kategori "Sangat Layak".

Media pembelajaran efektif untuk digunakan sebagai motivasi belajar peserta didik melalui teknologi dalam bentuk media pembelajaran berbasis macromedia flash. Mata pelajaran yang disampaikan dapat dimengerti oleh peserta didik dengan kolaborasi antara teks, animasi, gambar dan video. Peserta didik dapat melihat langsung bagaimana bentuk hewan dan tumbuhan melalui video yang ditampilkan dalam media pembelajaran. Hal ini berdasarkan hasil dari validasi uji coba perorangan dinilai sangat baik dengan persentase $82 \%$. Hasil penilaian dengan kriteria sangat baik dengan persentase $85 \%$ dari hasil validasi uji coba kelompok kecil. Dan hasil validasi dari uji coba kelompok besar dinilai baik dengan persentase $78 \%$.

\section{Daftar Pustaka}

Batubara, H. H. (2015). Pengembangan Media Pembelajaran Interaktif pada Materi Operasi Bilangan Bulat. MUALLIMUNA: Jurnal Madrasah Ibtidaiyah, 1(1), 1-12.

Carr, S. D., Halliday, A., King, A. C., Liedtka, J. \& Lockwood, T. (2010) The Influence of Design Thinking in Business : Some Preliminary Observations. Design Management Review, 21, 58 $-63$.

D.school. 2019 An Introduction to Design Thinking PROCESS GUIDE : Diperoleh dari 21 Februari 2021 dari https://dschool-

old.stanford.edu/sandbox/groups/designresources/wiki/36873/attachments/74b3d/ModeGuid eBOOTCAMP2010L.pdf?sessionID=1b6a96f1e2a50a3b1b7c3f09e58c40a062d7d553

Erma Novitasari, S., \& Surantoro. (2013). Pengembangan media pembelajaran berbasis IT berbentuk permainan ular tangga materi alat optik untuk kelas VIII SMP. Jurnal Pendidikan Fisika, Vol. 1 No. 1, 37 - 45.

Gibbons, S. (2019, agustus). Design Thinking 101. Diambil kembali dari Nielsen Norman Group : https://www.nngroup.com/articles/design-thinking/

Gilakjani, A. P. 2012. The significant role of multimedia in motivating EFL earners' interest in English language learning. I.J. Modern Education and Computer Science, Vol. 4, No .4, hlm. 57-66.

IDEO. (2020, februari). IDEO. Diambil kembali dari IDEO : https://www.ideou.com/pages/designthinking

Lee, L. 2006. Information and Communication Technologies: Transforming Views of Literacies in Early Childhood Settings. ISSN, Vol. 26, No. 1, hlm. 46-62.

Pressman, R.S., 2010, Software Engineering: a practitioner's approach, 7th Edition, McGraw-Hill, New York.

Profil Sekolah Dasar Negeri 26 Malabutor Kota Sorong Provinsi Papua Barat tahun 2018

Riduwan. 2010. Skala Pengukuran variable-variabel penelitian. Bandung: Alfabeta.

Satria, A. F. R., \& Ike Pertiwi Windasari (2015). Perancangan Aplikasi Pembelajaran "Fruvenimal" Berbasis HTML 5. Jurnal Teknologi dan Sistem Komputer, Vol. 3, No. 4, 421 - 425. https://jtsiskom.undip.ac.id/index.php/jtsiskom/article/view/12661/12280

Sugiono. 2012. Metode Penelitian Pendidikan : Pendekatan Kuantitatif, Kualitatif, dan R\&D. Bandung: Wacana Prima.

Sugiyono. (2013). Metode Penelitian Pendidikan : Pendekatan Kuantitatif, Kualitatif, dan R \& D. Bandung: Alfabeta.

Sugiyono. (2013). Statistika Untuk Penelitian. Bandung: Alfabeta.

Sutopo, Ariesto Hadi. (2012). Teknologi Informasi dan Komunikasi dalam Pendidikan. Yogyakarta : Graha Ilmu.

Wandah Wibawanto (2017). Desain dan Pemrograman Multimedia Pembelajaran Interaktir. Jember : Penerbit Cerdas Ulet Kreatif. 